\title{
Relationship between Knowledge and Premaretal Sex Attitudes in Adolescents in Kalipuro 3 Public Middle School
}

\author{
Hanien Firmansyah*, Ayik Mirayanti Mandagi \\ Airlangga University, Surabaya, Indonesia \\ hanien.firmansyah-2015@fkm.unair.ac.id
}

\begin{abstract}
Teenagers are a period that occurs in each from the first time showing secondary sexual signs to reach sexual maturity, psychological development, and patterns of thinking from childhood to adulthood. Sexual behavior is all behavior that is driven by sexual desire, whether done alone, with the opposite sex or same-sex without the marriage bond according to religion. This study aims to analyze the relationship between knowledge with premarital sex attitudes in adolescents in Kalipuro 3 Public Middle School. This type of research is quantitative with a cross-sectional design. The variables in this study are knowledge and premarital sex attitudes. Measurement of knowledge and attitudes is done by distributing questionnaires filled in by each student. Respondents of this study were all students of Kalipuro 3 Public Middle School totaling 84 students. Analysis of the data in this study using univariate analysis to see the description of respondents and bivariate analysis to see the relationship between knowledge variables with premarital sex attitudes. The results showed that the majority of respondents had poor knowledge of $39.3 \%$. The attitude variable shows that the majority of respondents have a bad attitude towards premarital sex which is equal to $56 \%$. A bad attitude is someone's attitude that leads to premarital sex. Bivariate analysis in this study shows the value of $p<\alpha(\alpha=0.05$; CI $=$ 95\%) which means that there is a relationship between knowledge with premarital sex attitudes in adolescents in Kalipuro 3 Public Middle School. The results of the study show that it is necessary to increase students' knowledge and attitudes through education and counseling learning to prevent premarital sex.
\end{abstract}

Keywords: Knowledge, Premaretal Sex Attitude, Relationship

Received December, 25, 2019; Revised January 24, 2020; Accepted February 15, 2020

STRADA Jurnal Ilmiah Kesehatan, its website, and the articles published there in are licensed under a Creative Commons Attribution-

ShareAlike 4.0 International License. 


\section{STRADA Jurnal Ilmiah Kesehatan}

DOI: $10.30994 /$ sjik.v9i1.267

ISSN: 2252-3847 (print); 2614-350X (online)

Vol.9 No.1. May 2020. Page.35-43

\section{INTRODUCTION}

Adolescence is a period that occurs in each from the first time showing secondary sexual signs to reach sexual maturity, psychological development, and patterns of thinking from childhood to adulthood. Adolescents experience a gradual transition that is at the stage of development characterized by a change in primary and secondary sex characteristics. During the transition period, sometimes teenagers have less knowledge about premarital sexual relations. This is caused by parents who feel taboo to discuss sexual problems with their children. Parent relations with distant children also cause children to seek information from other sources that are inaccurate and often cause sexuality problems (Sarwono, 2011).

Sexual behavior is all behavior that is driven by sexual desires both done alone, with the opposite sex and same-sex without marriage ties according to religion (Sarwono, 2011). Healthy and adaptive sexual behavior is carried out in a private place in a lawful manner, while premarital sexual behavior is sexual behavior that is carried out without going through an official marriage process according to the law or according to their respective religions and beliefs (Mu'tadin, 2010). Behaviors such as holding hands, kissing, flirting to intercourse are carried out with the encouragement of sexual desire, which is done before there is a marriage bond classified as premarital sex (Simanjuntak, 2010).

Forms of sexual behavior can be categorized into mild levels and severe levels. On a mild level is cuddling, kissing, and masturbation. The sexual behavior of the heavy level is petting and coitus (Hartono, 2010).

The results of a survey conducted by the Centers for Disease Control and Prevention (CDC) in 2015 to high school students in the United States showed that as many as $40 \%$ had had sexual relations, $30 \%$ of teenagers had had sexual relations for the previous 3 months. The 2013 BKKBN survey in Indonesia, children aged 10-14 years who have carried out activities to fulfill sexual urges reached $4.38 \%$ and at the age of 14-19 years it was $41.8 \%$. BKKBN's latest data from the Indonesian Adolescent Reproductive Health Survey said that 5,912 women aged 15-19 years had sexually nationally. Teenage boys at the same age numbered 6,578 , or $3.7 \%$ also had sex.

Risky sexual behavior among adolescents, especially unmarried teenagers tends to increase. It can be seen from the reports of the 2007 SKRRI and SKRRI 2012 data that teenagers dating in Indonesia tend to be bolder and more open, including holding hands in 2007 for $68.3 \%$ to $72 \%$ in 2012 and $69 \%$ to $80 \%$. Kissing men $41.2 \%$ to $48 \%$ and women 29.3 to $30 \%$. Groping / stimulating, men $26.5 \%$ increased to $30 \%$ while women were $9.1 \%$ to $6 \%$ in 2012.

Premarital sex in adolescence is at risk for the incidence of pregnancy and sexually transmitted diseases. Unplanned pregnancies can have further effects such as young marriage and abortion. Premarital sexual events occur because of curiosity, just happen, and are forced by a partner (InfoDATIN, 2014). This reflects the lack of understanding of teenagers about healthy life, the risk of sexual relations, and the ability to reject unwanted relationships. One way to prevent it is to increase knowledge and attitudes.

Low knowledge will affect the attitude of adolescents in behaving regarding premarital sex accompanied by strong peer influence in adolescence, making adolescents have unhealthy sexual acts that ultimately bring them closer to the risk of being infected with various types of sexually transmitted diseases, including HIV and AIDS ( Sulistianingsih, 2010). Good adolescent knowledge about premarital sex and its effects will make teens more careful not to take premarital sex. (Elyca, 2014). This is because one's knowledge will influence attitudes and actions that will be taken later (Notoatmodjo, 2012). 


\section{STRADA Jurnal Ilmiah Kesehatan}

DOI: $10.30994 /$ sjik.v9i1.267

ISSN: 2252-3847 (print); 2614-350X (online)

Vol.9 No.1. May 2020. Page.35-43

This study aims to analyze the relationship between knowledge and attitudes toward premarital sex in Kalipuro 3 Public Middle School.

\section{METHODS}

This type of research is quantitative with an analytical cross-sectional design where researchers do not only describe but also make observations and analyze relationships between variables. Respondents in this study were all students of Kalipuro 3 Public Middle School. In this study, no sampling was conducted because the respondents of this study were all students of Kalipuro 3 Public Middle School totaling 84 students. This research was conducted from July to August 2018.

The variables in this study are knowledge and premarital sex attitudes. Measurement of knowledge and attitudes is done by distributing questionnaires filled in by each student. Knowledge variables are grouped into three, namely good, sufficient, and bad. While attitude variables are grouped into two, namely good and bad. The inclusion criteria in this study were the status of Kalipuro 3 Public Middle School students. The exclusion criteria in this study were not at school at the time of the study.

The data used in this study are primary data and secondary data. Secondary data in this study were data of all Kalipuro 3 Public Middle School students obtained from the TU section. The primary data in this study is the level of knowledge and attitudes of students taken directly through the questionnaire shared.

Analysis of the data in this study using univariate analysis to see the description of respondents and bivariate analysis to see the relationship between knowledge variables with student attitudes toward premarital sex. Data analysis using Kolmogorov Smirnov to see the normality of data and then analyzed using chi-square to see the relationship between variables because the data is ordinal type.

\section{RESULTS}

This research was conducted in Kalipuro Banyuwangi 3 Public Middle School by taking the entire population of 84 people in this study who were students at Kalipuro 3 Public Middle School.

Distribution of characteristics of respondents in this study based on gender and age. Gender is divided into male and female.

Table 1. Distribution of Respondents by Gender

\begin{tabular}{llll}
\hline No & Gender & N & $\%$ \\
\hline 1 & Male & 47 & 55,95 \\
\hline 2 & Female & 37 & 44,05 \\
\hline Total & & 84 & 100 \\
\hline
\end{tabular}

Source: Primary Data, 2018

Table 1 shows that there are a majority of students male sex, namely as much as $55.95 \%$. In this study age, grouping was not carried out due to the age gap between respondents who were close together, besides that the age in this study was used as an illustration and no statistical analysis was carried out. 


\section{STRADA Jurnal Ilmiah Kesehatan}

DOI: $10.30994 /$ sjik.v9i1.267

ISSN: 2252-3847 (print); 2614-350X (online)

Vol.9 No.1. May 2020. Page.35-43

Table 2. Distribution of Respondents by Age

\begin{tabular}{llcl}
\hline No & $\begin{array}{c}\text { Age of } \\
\text { Respondents }\end{array}$ & N & $\%$ \\
\hline 1 & 12 Years & 17 & 20,24 \\
\hline 2 & 13 Years & 23 & 27,38 \\
\hline 3 & 14 Years & 24 & 28,57 \\
\hline 4 & 15 Years & 14 & 16,67 \\
\hline 5 & 16 Years & 5 & 5,95 \\
\hline 6 & 17 Years & 1 & 1,19 \\
\hline Total & & 84 & 100 \\
\hline
\end{tabular}

Source: Primary Data, 2018

The distribution of respondents by age in this study is illustrated in table 2 . The results of the study showed that the majority of respondents were at the age of 14 years as many as 28.57 respondents. But in general, the majority of students are at the age of 12-14 years. The description of respondents' knowledge in this study is divided into three, namely good, sufficient, and bad. Good categories based on 75-100 percentages are correct, enough categories are 56-74, and bad categories are $<56$.

Table 3. Overview of Respondents' Knowledge Levels

\begin{tabular}{llcc}
\hline No & Knowledge & N & $\%$ \\
\hline 1 & Well & 32 & 38,1 \\
\hline 2 & Enough & 19 & 22,6 \\
\hline 3 & Bad & 33 & 39,3 \\
\hline Total & & 84 & 100 \\
\hline
\end{tabular}

Source: Primary Data, 2018

The results of the study in table 3 show that the majority of respondents have poor knowledge that is equal to $39.3 \%$ but the amount is almost the same as the respondents with a good level of knowledge that is equal to $38.1 \%$.

Table 4. Overview of Respondents' Attitudes

\begin{tabular}{llll}
\hline No & Attitude & N & $\%$ \\
\hline 1 & Well & 37 & 44 \\
\hline 2 & Bad & 47 & 56 \\
\hline Total & & 84 & 100 \\
\hline
\end{tabular}

Source: Primary Data, 2018

The description of the respondent's attitude in this study is divided into two, namely good and bad. The results showed that the majority of respondents had a bad attitude which was as much as $56 \%$. The bad attitude in this study is that the respondents are towards the direction of premarital sex.

Bivariate analysis in this study was conducted to analyze the relationship between knowledge and respondents' attitudes toward premarital sexual behavior in adolescents. Most of the respondents had bad knowledge and attitudes towards premarital sex, which amounted to $93.93 \%$. However, these results are almost the same as respondents who have good knowledge and attitudes that are equal to $81.25 \%$. 


\section{STRADA Jurnal Ilmiah Kesehatan}

DOI: $10.30994 /$ sjik.v9i1.267

ISSN: 2252-3847 (print); 2614-350X (online)

Vol.9 No.1. May 2020. Page.35-43

Table 5. Chi-Square Test Results between Knowledge and Premarital Sex Attitudes

\begin{tabular}{lccccccc}
\hline \multicolumn{1}{c}{ Variable } & \multicolumn{3}{c}{ Attitude } & \multicolumn{2}{c}{ Total } & \multirow{2}{*}{$\mathrm{p}$} \\
\cline { 2 - 6 } Knowledge & \multicolumn{2}{c}{ Bad } & \multicolumn{2}{c}{ Well } & & \\
& $\mathrm{N}$ & $\%$ & $\mathrm{~N}$ & $\%$ & $\mathrm{~N}$ & $\%$ & \\
\hline Bad & 31 & 93,93 & 2 & 6,06 & 33 & 100 \\
\hline Enough & 10 & 52,63 & 9 & 47,37 & 19 & 100 \\
\hline Well & 6 & 18,75 & 26 & 81,25 & 32 & 100 & \\
\hline
\end{tabular}

Source: Primary Data, 2018

The results showed that the $\mathrm{p}$-value was 0,000 . This shows $\mathrm{p}<\alpha(\alpha=0.05)$, meaning that there is a relationship between knowledge with premarital sex attitudes in adolescents in Kalipuro 3 Public Middle School.

\section{DISCUSSION}

In this study, respondents amounted to 84 people with the majority of men being equal to $55.95 \%$ while respondents of female sex were $44.05 \%$. While viewed in terms of age, the majority are 14 years old, which is $28.57 \%$. This age is in the category of early adolescents who begin to be in the stage of searching for identity and enjoy hanging out with peers. Age 13-15 years is the age in middle teens where the knowledge and experience of a teenager are still lacking. At the age of middle teens they begin to feel like looking for self-identity, appearing the desire to date, attraction with the opposite sex, arising feelings of deep love, and the ability to fantasize increasingly developed and have begun fantasizing about matters relating to sex, lack of knowledge leads to adolescents tend to find out and want to try things related to sex so that this will affect the attitude of adolescents to sex (Widiastuti, 2009).

Based on the description of knowledge, in this study, the majority of respondents have a poor level of knowledge that is equal to $39.3 \%$ while those who have good knowledge are $38.1 \%$. The results of this study are similar to the research conducted by Sofia et al (2017) that the majority of students have a poor level of knowledge about premarital sex, which is $34 \%$. However, the results of this study show different results from the research conducted by Naedi (2012) where the majority of adolescents in these schools have a good level of knowledge that is equal to $96.6 \%$ ).

This can be related to the factors of information obtained by students, the high and low knowledge of adolescents about premarital sex-related to information and education obtained by someone in their environment (Lenawida, 2014). The low level of adolescent knowledge can cause an impact that destroys the future of adolescents. Therefore, integrated efforts are needed starting from family, school, and the surrounding environment so that adolescents can obtain accurate information about premarital sex (Tarwoto, 2010).

Attitude is a reaction of one's feelings towards something both in the form of support and rejection (Azwar, 2015). The results showed that the majority of respondents had a bad attitude $56 \%$ while $44 \%$ had a good attitude. Bad attitudes in research are adolescent attitudes that lead to premarital sex while a good attitude in this study is intended to attitudes of adolescents who refuse premarital sex. This research shows the same results with Firdha's (2012) research on the description of adolescent attitudes in Makassar Public 


\section{STRADA Jurnal Ilmiah Kesehatan}

DOI: $10.30994 /$ sjik.v9i1.267

ISSN: 2252-3847 (print); 2614-350X (online)

Vol.9 No.1. May 2020. Page.35-43

High School 5 which shows that the majority of teenagers tend to behave toward premarital sex. The results of this study can be influenced by the level of poor respondents' knowledge that allows a person to be bad about something. In addition, the condition of the surrounding community which often mentions sexual matters can be one of the factors that cause the majority of students to have bad attitudes or attitudes that lead to premarital sex, this occurs because the majority of students are native to the area so that the intensity of association with the surrounding environment school is also high (Tias, 2015).

The results of the study after statistical tests using chi-square showed the value of $p<\alpha$ ( $\alpha$ $=0.05$ ) which means that there is a relationship between knowledge with premarital sex attitudes in adolescents. The majority of respondents in this study had bad knowledge and attitudes which amounted to $93.93 \%$.

The results of the study of statistical tests using chi-square showed the value of $p<\alpha(\alpha=$ 0.05) which means that there is a relationship between knowledge with premarital sex behavior in adolescents. The study had a bad knowledge and attitude which amounted to 93.93\%.

Attitude is a reaction or response that is still closed from someone to a stimulus or object. Attitudes can be positive or negative (Andriana, 2014). Knowledge influences in forming attitudes because it has a basis of understanding and moral concepts in individuals, understanding will be good-bad, the dividing line between something that may or may not is done (Rejeki and Tinah, 2010).

Research conducted by Pawestri et al (2013) showed a significant relationship between knowledge and the incidence of premarital sex. A person's attitude is closely related to one's level of knowledge. A person's attitude towards a matter shows the person's knowledge of it. So that it can be concluded that adolescents who have good knowledge about premarital sex, they will tend to have a positive attitude (tendency to avoid premarital sexual behavior). Conversely, adolescents who have less knowledge about premarital sex tend to have negative attitudes (a tendency to approach premarital sexual behavior) (Walgito, 2013). These results are also in line with research conducted by Maolinda (2012) and Kusumawati (2010) which shows that there is a relationship between knowledge with premarital sex attitudes in adolescents of school-age or middle adolescents.

Knowledge of premarital sex in adolescents can influence adolescent attitudes toward premarital sex. This is because knowledge is one of the important factors in forming the attitude of a teenager entering the transition period and knowledge can also change one's perception of sexuality (Adikusumo, 2005). Research conducted by Dewi (2007), that of the 150 respondents, $88.7 \%$ of adolescents found positive attitudes towards sexuality (a tendency to avoid premarital sexual behavior). This is because most teenagers have a perception that sex should be done after a legitimate marriage bond. In their thinking, if premarital sex in adolescence will hurt their future and mental development (Dewi, 2011).

Adolescents who have a good attitude assume that having sexual relations before marriage is a wrong act so that the number of premarital sexual events tends to decrease. However, adolescents who have bad behavior are at risk of behaving according to their opinions because they feel agreed to do so. But often in real life, many other factors affect a person, not just one's attitude and knowledge, but can also be a social environment, situation or opportunity. As a result, their behavior is not consistent with their knowledge and attitudes (Notoatmodjo, 2012). Negative behavior will tend to increase along with adolescence is a period of change where they have narcissistic behavior that is an increasingly free 


\section{STRADA Jurnal Ilmiah Kesehatan}

DOI: $10.30994 /$ sjik.v9i1.267

ISSN: 2252-3847 (print); 2614-350X (online)

Vol.9 No.1. May 2020. Page.35-43

association, curiosity and the search for identity so that it is very vulnerable to take actions or actions that harm themselves (Rina, 2015).

Positive attitudes of teenagers can prevent them from premarital sexual behavior. This attitude is influenced by several factors, one of which is knowledge. A good person's knowledge will tend to make someone take a positive attitude (Citra, 2017). Good knowledge will make teenagers or students realize the effects of premarital sex such as sexually transmitted diseases and extramarital pregnancies. Because it requires a clear exposure of information to students so that they understand the dangers of premarital sex so that they can take a position to distance themselves from these behaviors.

Research conducted by Nurkhasanah (2015) shows that the provision of premarital sexual education has a stake in a person to prevent premarital sexual behavior. Other research conducted by Rahmawati (2017) shows that good adolescent knowledge can influence adolescent behavior. The better knowledge a person has on premarital sex will make them understand the risks and premarital sex prevention measures. Students will consider good and bad when they take action.

\section{CONCLUSION}

The knowledge of Kalipuro 3 Public Middle School students is still bad about premarital sex as well as their attitude towards premarital sex. The results of the analysis showed that there was a relationship between knowledge with premarital sex attitudes in adolescents in Kalipuro 3 Public Middle School.

Education is one way to prevent premarital sex through increasd knowledge and attitude formation. Besides that, building a positive environment both at school and at home is needed in preventing premarital sex. The school is certainly expected to create a counseling program to prevent juvenile delinquency such as premarital sex to create a quality person for the progress of the Indonesian nation.

\section{REFERENCES}

Azwar, S. (2015). Penyusunan Skala Psikologi Edisi 2. Yogyakarta: Pustaka Belajar.

Andriana, D. (2014). Faktor-faktor yang Berhubungan dengan Perilaku Seks Pranikah pada Mahasiswa UNNES. UNNES Journal of Public Health, 3(4): 27-38.

Aritonang, \& Rina, T. (2015). Hubungan Pengetahuan dan Sikap Tentang Kesehatan Reproduksi dengan Perilaku Seksual Pranikah Pada Remaja Usia (15-17 Tahun) di SMK Yadika 13 Tambun, Bekasi. Jurnal Ilmiah WIDYA. Vol.3 No.2 Septermber-Desember 2015.

CDC. Sexual Risk Behaviors: HIV, STD, \& Teen Pregnancy Prevention 2015. Available from: http://www.cdc.gov/healthyyouth/sexualbehaviors/index .htm.

Dewi, E., S. (2011). Hubungan antara persepsi tentang seks dan perilaku seksual remaja di SMA Negeri 3 Medan. (diakses tanggal 4 Juni 2019) http://repository.usu.ac.id/bitstream/1 23456789/21172/1/ruf-nov2007$2 \% 20(3)$.pdf. 


\section{STRADA Jurnal Ilmiah Kesehatan}

DOI: $10.30994 /$ sjik.v9i1.267

ISSN: 2252-3847 (print); 2614-350X (online)

Vol.9 No.1. May 2020. Page.35-43

Febrianti, S., Robby, A., \& Tetet, K. (2018). Gambaran Pengetahuan Remaja Tentang Dampak Seks Pranikah Di Salah Satu Sma Kota Tasikmalaya. Jurnal Kesehatan Bakti Tunas Husada, 17(2), 261-267.

Firdha, J. (2012). SKRIPSI: Analisis Gambaran Pengetahuan dan Sikap Remaja di SMA Negeri 5 Makassar. Makassar: Universitas Hasanuddin Makassar.

Hartono. (2010). Hubungan Kemampuan Mengontrol Diri dan Kecenderungan Situs Porno pada Remaja. Jakarta: Guna Darma.

Infodatin. (2014). Situasi Kesehatan Reproduksi Remaja. Kementerian Kesehatan.

Kusumastuti, FAD., (2010). Hubungan antara Pengetahuan dengan Sikap Seksual Pranikah Remaja. KTI. Program Studi DIV Kebidanan Fakultas Kedokteran Universitas Sebelas Maret, Surakarta.

Lenawida. (2014). Pengetahuan Remaja Tentang Perilaku Seksual Pranikah Di Gampong Batoh Kecamatan Lueng Bata Kota Banda Aceh. Aceh. Jurnal Kesehatan Ilmiah Nasuwakes Vol.7 No.2. Diakses secara online melalui http://nasuwakesaceh.ac.id/gudang/file/pdf/jurnal-pdf i1TlrX4mJ1CIpnO2 .pdf. Pada tanggal 20 Juli 2019.

Maolinda, N., Sriati, A., \& Maryadi, I. (2012). Hubungan Pengetahuan dengan Sikap Siswa terhadap Pendidikan Kesehatan Reproduksi Remaja di SMAN Margahayu. FIK Universitas Padjajaran, Bandung.

Mu'tadin, Z. (2010). Kemandirian sebagai Kebutuhan Psikologis Remaja. Internet. http://www.e-psikologi.com/remaja.050602.

Natalia Mangando, E., S., Lampus, B., S., Siagian, I., E., Kandou, G., D., Pandelaki, A., \& Kaunang, W., P. (2014). Hubungan Antara Pengetahuan dan Sikap Remaja Dengan Tindakan Seks Pranikah pada Siswa Kelas XI Di SMK Negeri 2 Manado. Jurnal Kedokteran Komunitas Dan Tropik, II, 37-43.

Naedi. (2012). Gambaran Tingkat Pengetahuan Seks Bebas pada Remaja Kelas XI di SMA Negeri 1 Cileungsi Kabupaten Bogor. Diunduh 24 Februari 2019. Didalam http://lib.ui.ac.id/file?file=digital/20 312638-S\%2043154Gambaran\%20tingkatfull\%20text.pdf.

Notoatmodjo, S. (2012). Promosi Kesehatan dan Perilaku Kesehatan. Jakarta: Rineka Cipta.

Oktiva, Y., D., \& Muhlisin, A. (2010). Hubungan antara Tingkat Pengetahuan tentang Kesehatan Reproduksi Remaja dan Pola Asuh Orang Tua dengan Sikap Remaja tentang Seks Bebas di SMAN 1 Tawangsari Sukoharjo.

Pawestri, Wardani, R., S., \& Sonna. (2013). Pengetahuan, Sikap dan Perilaku Remaja tentang Seks Pra Nikah. Keperawatan Maternitas, 1(1), 46-54. 


\section{STRADA Jurnal Ilmiah Kesehatan}

DOI: $10.30994 /$ sjik.v9i1.267

Puspitaningrum, D., \& Damayanti, F., N. (2012). Analisis Faktor-Faktor yang Mempengaruhi Remaja Putri dengan Perilaku Pencegahan Seks Bebas. Jurnal Kebidanan dan Keperawatan, 8, 101-110.

Rezeki, Sri, \& Tinah. (2010). Hubungan Pengetahuan dan Sikap Remaja tentang Reproduksi dengan Perilaku Seks Pranikah. Jurnal Kebidanan. II(02): 28-39.

Sarwono, W., S. (2011). Psikologi Remaja. Edisi Revisi Cetakan 14. Jakarta: PT. Rajawali Grafindo Persada.

Simanjuntak. (2010). Pengantar Psikologi Perkembangan. Jakarta: PT. Gramedia Utama.

Sulistianingsih, A. (2010). Hubungan lingkungan pergaulan dan pengetahuan tentang kesehatan reproduksi dengan sikap seks bebas remaja. Skripsi. Universitas Sebelas Maret; Surakarta.

Tarwoto. (2010). Kesehatan Remaja Problem dan Solusinya. Jakarta: Salemba Medika.

Tias, A., R., F. (2015). Hubungan antara Lingkungan Pergaulan dengan Sikap dan Perilaku Seks Bebas Remaja di SMK Murni 2 Surakarta. Universitas Muhammadiyah Surakarta.

Walgito, B. (2013). Psikologi sosial (suatu pengantar). Yogyakarta: Andi Offset.

Widyastuti, Y. (2009). Kesehatan Reproduksi. Yogyakarta: Fitramaya. 